\title{
IMPACT OF HUMAN RESOURCE MANAGEMENT ON BUSINESS PERFORMANCE: A REVIEW OF LITERATURE
}

\author{
UDC: 005.96:005.336.1 \\ Original Scientific Paper \\ Mihalj BAKATOR ${ }^{1}$, Nikola PETROVIĆ ${ }^{2}$, Slađana BORIĆ ${ }^{2}$, Nataša ĐALIĆ ${ }^{2}$ \\ ${ }^{1}$ University of Novi Sad, Technical Faculty "Mihajlo Pupin", 23000 Zrenjanin, Đure Đakovića bb, \\ Republic of Serbia \\ E-mail: mihalj.bakator@uns.ac.rs \\ ${ }^{2}$ Republic of Serbia
}

Paper received: 20.01.2019.; Paper accepted: 25.03.2019.

\begin{abstract}
In this paper the influence of human resource management (HRM) on business performance is analyzed. The main goal was to thoroughly and systematically examine literature in the domain of HRM, and business performance that resulted in a concise review paper. A large body of literature addresses the HRM-business performance link, thus there was plenty of room for an extensive analysis of various articles. To be more precise, two hundred and twelve (212) articles were analyzed from which 187 were removed through several steps in the review process. The findings indicate that there is a positive relationship between HRM practices and overall business performance. In addition, HRM has a positive influence on employee wellbeing, productivity, and organizational climate. However, there is a possibility that good HRM practices are not the cause of good business performance, but vice-versa. This issue is addressed, and discussed further in this present article. Based on the gathered information, and obtained results, it is safe to suggest that this systematic review paper has a significant contribution to the existing body of literature. In addition, the paper can be used as a starting point for future research in the domain of HRM practices and their impact on business performance.
\end{abstract}

Keywords: Human resource management, Business performance, Employee productivity, Business strategy.

\section{INTRODUCTION}

A study conducted by (Akhtar et al., 2008) suggested that there is a possible link between adequate human resource management (HRM) and increase of business performance. Namely, training and internal career opportunities positively affected product, and service performance (Stavrou et al., 2010). Similarly, in the research of (Björkman \& Xiucheng, 2002), it was noted that firm performance is positively correlated with high-performance HRM systems. HRM systems are closely linked with business strategies, thus it positively affects business performance as well (Lee et al., 2010). However, (Apospori et al., 2008) argued that HRM may have a different influence on company performance in different environments (geographical location, competitors, market etc.). The influence of HRM systems depends on various influential factors, and it is not always certain in what way will certain human resource actions affect business performance (Subramony, 2009). It is negligent to assume that HRM practices could definitively improve company performance (Wall \& Wood, 2016). Based on the mentioned findings it is evident that there is room for future research in this domain.

The aim of this paper is to systematically analyze literature in the domain of HRM and its influence on business performance. HRM is often important for companies to achieve competitiveness on the market (Pološki et al., 2008; Saha et al., 2017). Further, the competitiveness of companies is crucial for long-term business excellence (Đorđevi et al., 2016). The relationships between employees are complex. Therefore, the analysis of how HRM systems affect business performance is welcomed. 
There is a large body of literature on HRM systems, and the various effects they have on employees. This present study provides a concise systematic review of the impact that HRM has on companies' competitiveness, and overall business performance. The review focuses on answering three main research questions:

\section{How does HRM affect overall business performance?}

2. Are HRM systems an imperative for high performance in companies?

3. Is HRM a necessity for good relationships between employees?

In order to answer these research questions this review paper includes three main sections. The first section describes the review methodology that was used to analyze, and obtain qualitative and quantitative data from various articles in the domain of HRM. In the second section, the individual results of each reviewed article are presented. In addition, a concise synthesis of the results is shown. In the third section the results are discussed, and the contribution of this paper is outlined. Finally, conclusions are drawn, and suggestions for future research are made.

\section{METHODOLOGY}

\section{Flow diagram}

The whole review process was conducted in accordance with the PRISMA protocol (Moher et al., 2010). This protocol consists of four main sections. First, the identification of articles from various scientific sources is conducted. In the second section, the screening process is conducted. At this stage a large number of articles are analyzed in order to exclude inadequate articles. Next, the remaining articles are screened for eligibility. In the final section the articles are analyzed, and qualitative results are obtained. The PRISMA protocol is shown in Figure 1.

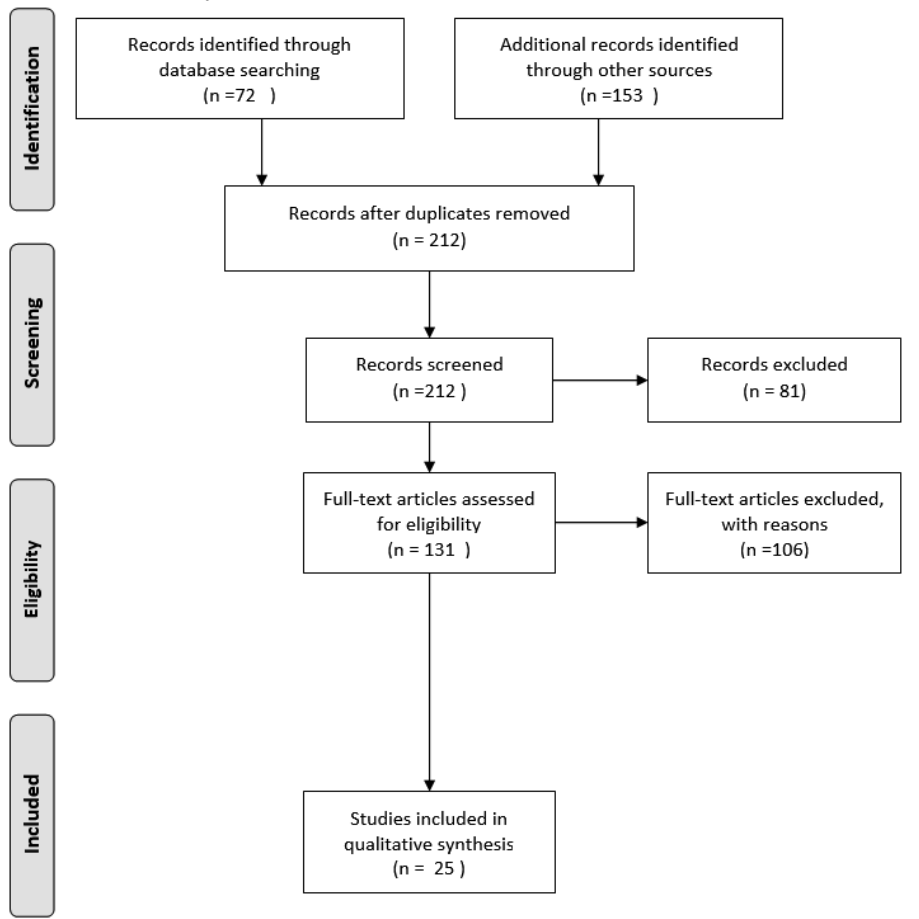

Figure 1: Protocol diagram of the review process

The total number of analyzed articles was 212 . The number of studies included in this present paper is 25. As mentioned before, in the eligibility section of the review process, full-text articles were reviewed and excluded with reasons.

\section{Literature sources}

With the goal to review adequate articles published in the domain of HRM, credible journals were addressed as main sources of literature. The majority of the reviewed articles were published in five scientific journals. The details of these journals are given in Table 1. 
Table 1: Main literature sources

\begin{tabular}{|c|l|c|l|}
\hline$\#$ & \multicolumn{1}{|c|}{ Scientific journal } & \multicolumn{1}{c|}{ ISSN } & \multicolumn{1}{c|}{ Publisher } \\
\hline 1. & Management Revue & $0935-9915$ & Rainer Hampp Verlag \\
\hline 2. & Human Resource Management Journal & $1748-8583$ & John Wiley \& Sons Ltd \\
\hline 3. & Human Resource Management & $1099-050 X$ & Wiley Periodicals, Inc. \\
\hline 4. & Academy of Management Journal & $0001-4273$ & Academy of Management \\
\hline 5. & $\begin{array}{l}\text { The International Journal of Human } \\
\text { Resource Management }\end{array}$ & $0958-5192$ & Taylor \& Francis \\
\hline
\end{tabular}

Source: Developed for this research

\section{Data/article collection process}

The articles were searched through the Google Scholar service, and through the KoBSON service. Potentially adequate articles were downloaded, and imported into an article organizing software. This way duplicates could be removed, and articles from inadequate sources were excluded. In the search process, the following keywords were used:

- human resource management and business performance,

- HRM and business performance,

- human resource management and company performance,

- HRM and company performance,

- HRM systems and employee productivity,

- human resource management systems and productivity,

- HRM and employee wellbeing,

- human resource management and organizational performance,

- HRM and firm performance,

- human resource management and firma performance.

It is important to note that the concepts of "business performance", "firm performance", "overall performance", "organizational performance" and "company performance" refer to the same construct that includes one or several of the following dimensions: employee wellbeing, employee skills, organizational productivity, cooperation between employees, productivity, turnover, clarity of strategic goals, organizational culture, finance, organizational effectiveness, employment security, organizational innovation, strategy innovation, employee motivation, recruitment process, knowledge acquiring, strategy outcomes, resource management, staffing, and employee development.

This was done in order to simplify the review process, as the main goal is to concisely present the potential influence of HRM on business performance. However, in the results section, the individual results were not simplified, and more detail was given for each reviewed article.

\section{Obtained literature and eligibility criteria}

The obtained articles were imported in an article organizing software. First the duplicates were removed. Afterwards, every article was analysed in order to determine their eligibility for further review. Through several elimination steps, the remaining articles were further examined, and the results were noted. The eligibility criteria included the following:

- articles are published in non-predatory conferences, and journals,

- articles examine the importance of HRM, and HRM systems,

- articles investigate the influence of HRM and HRM systems on business performance,

- articles provide sufficient detail about the sample which was used for the research.

In addition, articles that are published as systematic review papers, or meta-analyses papers were also considered. However, the focus was on empirical research papers. There were no specific restrictions regarding the year of publishing. Similarly, journal issue, volume, and number were not taken into consideration, as this would not affect the obtained results.

\section{Risk of bias in individual studies}

It was mentioned in the previous section that year of publication was not strictly defined. However, to avoid year of publication bias, the earliest article reviewed dates from 1996, and the latest is from 2018. It was ensured that the results from different articles were not obtained from the same samples. There were no specific journals aimed for the review. The source of the articles was examined after the collected information, and only predatory journals and conference papers were excluded. In the next section the results of individual studies and the synthesis of results are presented. 
M. Bakator Impact of human resource management on business performance:

et al. A review of literature

\section{RESULTS}

\section{Individual studies}

In accordance with the main subject of this systematic review, proper details, and data were obtained from individual articles. Therefore, the results of individual studies include the author/s of the publication, the findings of that particular study, and additional details of the study. These individual results are grouped by year of article publication. In Table 2, the results of articles published between 1996 and 2000 are presented.

Table 2: Results of individual studies published between 1996 and 2000

\begin{tabular}{|c|l|l|l|}
\hline ID & \multicolumn{1}{|c|}{ Authors } & \multicolumn{1}{c|}{ Findings } & \multicolumn{1}{c|}{ Research details } \\
\hline A1 & $\begin{array}{l}\text { (Delery \& } \\
\text { Doty, 1996) }\end{array}$ & $\begin{array}{l}\text { The results indicated there is a universal relationship } \\
\text { between human resource practices and accounting } \\
\text { measures of performance. In addition, a strong } \\
\text { relationship is noted between profit sharing and } \\
\text { employee rewarding strategies. Further, HRM was } \\
\text { positively correlated to employment security. }\end{array}$ & $\begin{array}{l}\text { A total of 1050 banks were } \\
\text { included in the survey. The } \\
\text { research included two different } \\
\text { surveys. The first survey was } \\
\text { meant for human resource } \\
\text { managers, and the second } \\
\text { survey was aimed at the bank } \\
\text { clerks. }\end{array}$ \\
\hline A2 & $\begin{array}{l}\text { (Delaney \& } \\
\text { Huselid, } \\
1996)\end{array}$ & $\begin{array}{l}\text { The study finds no evidence of positive relationship } \\
\text { between HRM and company performance. } \\
\text { Furthermore, even advanced HRM strategies are not } \\
\text { complementary to enhanced business performance. }\end{array}$ & $\begin{array}{l}\text { 727 organizations were } \\
\text { interviewed via survey and } \\
\text { telephone survey. }\end{array}$ \\
\hline A3 & $\begin{array}{l}\text { (Harel \& } \\
\text { Tzafrir, } \\
1999)\end{array}$ & $\begin{array}{l}\text { The study showed that organizations which treated } \\
\text { their employees as important assets had a higher } \\
\text { perception of business performance. }\end{array}$ & $\begin{array}{l}\text { 760 organizations which employ } \\
\text { more than 200 workers, were } \\
\text { surveyed. }\end{array}$ \\
\hline A4 & $\begin{array}{l}\text { (Bae \& } \\
\text { Lawler, } \\
\text { 2000) }\end{array}$ & $\begin{array}{l}\text { The results of the research indicated that HRM } \\
\text { strategies that practice high involvement of } \\
\text { employees, have a positive effect on business } \\
\text { performance. }\end{array}$ & $\begin{array}{l}\text { The research was sampled from } \\
\text { randomly chosen local } \\
\text { companies in South Korea. All } \\
\text { of these companies had at least } \\
50 \text { employees. }\end{array}$ \\
\hline
\end{tabular}

Grouping the individual results by year of article publication, gives a more adequate overview of the obtained results. It is important to note, that there was no bias towards certain publication years. This resulted in a non-continuous year of publication among the individual results. Next, the results of individual studies published between 2003 and 2006 are presented in Table 3

Table 3: Results of individual studies published between 2003 and 2006

\begin{tabular}{|c|l|l|l|}
\hline ID & \multicolumn{1}{|c|}{ Authors } & \multicolumn{1}{c|}{ Findings } & \multicolumn{1}{c|}{ Research details } \\
\hline A5 & $\begin{array}{l}\text { Guest, } \\
\text { Michie, } \\
\text { Conway, \& } \\
\text { Sheehan, } \\
\text { 2003) }\end{array}$ & $\begin{array}{l}\text { Interestingly, the results indicated that there is no } \\
\text { correlation between HRM practice and improved } \\
\text { performance. However, it was noted that there is a } \\
\text { slightly positive relationship between HRM and } \\
\text { lower work turnover. In contrast, the relationship was } \\
\text { observed between human resource practices and } \\
\text { productivity. }\end{array}$ & $\begin{array}{l}\text { 366 companies successflly } \\
\text { completed the survey and were } \\
\text { eligible for further data } \\
\text { processing. }\end{array}$ \\
\hline A6 & $\begin{array}{l}\text { (Ahmad \& } \\
\text { Schroeder, } \\
\text { 2003) }\end{array}$ & $\begin{array}{l}\text { This research noted that there is a positive } \\
\text { relationship between business performance and the } \\
\text { following HRM practices: selective hiring, self- } \\
\text { managed teams, using compensation contingents, and } \\
\text { organizational performance. }\end{array}$ & $\begin{array}{l}\text { 107 manufacturing companies } \\
\text { were included in the research. }\end{array}$ \\
\hline A7 & $\begin{array}{l}\text { (Gelade \& } \\
\text { Ivery, 2003) }\end{array}$ & $\begin{array}{l}\text { In this study it was noted that there is a partial } \\
\text { relationship between HRM, organizational climate } \\
\text { and performance. The main components of the HRM } \\
\text { variable were working overtime, staffing, and } \\
\text { professional development of employees. }\end{array}$ & $\begin{array}{l}\text { The sample for this research } \\
\text { included 137 brand director } \\
\text { groups that represent a cluster of } \\
\text { bank branches. }\end{array}$ \\
\hline
\end{tabular}


Table 3: Results of individual studies published between 2003 and 2006. (extension)

\begin{tabular}{|c|c|c|c|}
\hline ID & Authors & Findings & Research details \\
\hline A8 & $\begin{array}{l}\text { (Collins \& } \\
\text { Clark, 2003) }\end{array}$ & $\begin{array}{l}\text { The results of this research supported the notion that } \\
\text { HRM has a positive relationship with higher business } \\
\text { performance. This performance increase is the result } \\
\text { of reinforcing and developing resources that are } \\
\text { based on the employees. }\end{array}$ & $\begin{array}{l}73 \text { high-technology companies } \\
\text { in the mid-Atlantic region of the } \\
\text { USA, participated in the survey. }\end{array}$ \\
\hline A9 & $\begin{array}{l}\text { (Datta, et al., } \\
\text { 2005) }\end{array}$ & $\begin{array}{l}\text { It was noted that the relationship between HRM and } \\
\text { business performance, is dependent on the type of } \\
\text { research that is conducted. }\end{array}$ & $\begin{array}{l}132 \text { manufacturing companies } \\
\text { with a minimum of } 100 \\
\text { employees were surveyed. }\end{array}$ \\
\hline A10 & $\begin{array}{l}\text { (Gerhart, } \\
\text { 2005) }\end{array}$ & $\begin{array}{l}\text { It was concluded that there are certain limitations } \\
\text { when it comes to linking HRM and business } \\
\text { performance. This study argues that business } \\
\text { performance and great employee relationships can be } \\
\text { achieved without HRM. }\end{array}$ & $\begin{array}{l}\text { This study reviewed articles } \\
\text { regarding human resource } \\
\text { management between } 1995 \text { and } \\
2005 \text {. }\end{array}$ \\
\hline A11 & $\begin{array}{l}\text { (Stavrou \& } \\
\text { Brewster, } \\
2005)\end{array}$ & $\begin{array}{l}\text { The research suggested that training, and developing } \\
\text { employees positively affected organizational } \\
\text { productivity, and employee skills. In addition, } \\
\text { through an effective HRM, organizations can control } \\
\text { external pressures and situations more effectively. }\end{array}$ & $\begin{array}{l}\text { Data was collected form } 3702 \\
\text { for-profit businesses. }\end{array}$ \\
\hline A12 & $\begin{array}{l}\text { (Lambooij, } \\
\text { et al., 2006) }\end{array}$ & $\begin{array}{l}\text { In this study no support was found for the proposition } \\
\text { that better strategic, and internal HRM links to a } \\
\text { higher cooperation of employees. }\end{array}$ & $\begin{array}{l}\text { In this research } 723 \text { employees } \\
\text { participated from } 10 \text { different } \\
\text { organizations. }\end{array}$ \\
\hline A13 & $\begin{array}{l}\text { (Boselie et } \\
\text { al., 2005) }\end{array}$ & $\begin{array}{l}\text { This systematic review noted that there are severe } \\
\text { limitations when it comes to measuring HRM } \\
\text { efficiency and its impact on business performance. } \\
\text { Therefore, it cannot be concluded that HRM has a } \\
\text { positive impact on business performance. }\end{array}$ & $\begin{array}{l}\text { The review included articles } \\
\text { between } 1994 \text { and } 1995 . \text { In } \\
\text { addition, studies from } 2003 \\
\text { were also addressed. }\end{array}$ \\
\hline A14 & $\begin{array}{l}\text { (Vanhala \& } \\
\text { Tuomi, } \\
\text { 2006) }\end{array}$ & $\begin{array}{l}\text { Contradictory to previous studies, this article argues } \\
\text { that there is no evidence of positive relationship } \\
\text { between any type of HRM practice and company } \\
\text { performance. }\end{array}$ & $\begin{array}{l}235 \text { companies in } 1997 ; 2599 \\
\text { employees in } 1998 ; 91 \\
\text { companies and } 1389 \text { employees } \\
\text { between } 1997 \text { and } 2000 \text { were } \\
\text { surveyed. }\end{array}$ \\
\hline
\end{tabular}

Source: Developed for this research

As mentioned before articles are published based on year of publication, not by the year when the data from companies was collected. However, this doesn't affect the main goal of this paper which is: Determining the potential influence of HRM on business performance. Further, in Table 4, the individual results obtained from articles published between 2007 and 2010 are presented.

Table 4: Results of individual studies published between 2007 and 2010

\begin{tabular}{|c|l|l|l|}
\hline ID & Authors & \multicolumn{1}{|c|}{ Findings } & \multicolumn{1}{c|}{ Research details } \\
\hline A15 & $\begin{array}{l}\text { (Renee } \\
\text { Baptiste, } \\
2008)\end{array}$ & $\begin{array}{l}\text { The study addressed the positive benefits of HRM on } \\
\text { employees. The results indicate that additional } \\
\text { management support increased employee wellbeing. } \\
\text { It can be argued that increased employee wellbeing } \\
\text { has a positive impact on organizational performance. }\end{array}$ & $\begin{array}{l}\text { 51 employees from a local } \\
\text { government organizations } \\
\text { participated in the survey. }\end{array}$ \\
\hline A16 & $\begin{array}{l}\text { (Sun et al., } \\
2007)\end{array}$ & $\begin{array}{l}\text { The study revealed that HRM which incorporated } \\
\text { high-performance human resource training was } \\
\text { positively correlated to productivity, turnover, and } \\
\text { overall business performance. }\end{array}$ & $\begin{array}{l}\text { The data was collected from } \\
\text { hotels located in 12 different } \\
\text { cities in China. }\end{array}$ \\
\hline
\end{tabular}


Table 4: Results of individual studies published between 2007 and 2010 (extension)

\begin{tabular}{|c|l|l|l|}
\hline ID & Authors & \multicolumn{1}{c|}{ Findings } & \multicolumn{1}{c|}{ Research details } \\
\hline A17 & $\begin{array}{l}\text { (Bartra et al., } \\
\text { 2007) }\end{array}$ & $\begin{array}{l}\text { In this research it was suggested that there are } \\
\text { positive associations between HRM functions and } \\
\text { cost-effective outcomes. In addition, the results } \\
\text { indicated that women reported higher levels of } \\
\text { negative interaction regarding human resource } \\
\text { management, in opposite to male employees. Other } \\
\text { organizational factors such as strategic goals clarity, } \\
\text { company history, and organizational culture also } \\
\text { have an impact on the perception of human resource } \\
\text { management efficiency. }\end{array}$ & $\begin{array}{l}\text { The data was collected via a } \\
\text { survey from 132 healthcare } \\
\text { facilities in Victoria, Australia. }\end{array}$ \\
\hline A18 & $\begin{array}{l}\text { (Chand \& } \\
\text { Katou, 2007) }\end{array}$ & $\begin{array}{l}\text { The findings of this research indicate that there is a } \\
\text { positive relation between HRM systems, and the } \\
\text { following performance indicators: manpower } \\
\text { planning, pay systems, recruitment and selection, } \\
\text { training and development, and overall business } \\
\text { performance. }\end{array}$ & $\begin{array}{l}\text { The data for this research was } \\
\text { obtained from 439 hotels. The } \\
\text { survey was self-administered } \\
\text { and investigated 27 human } \\
\text { resource management practices. }\end{array}$ \\
\hline A25 & $\begin{array}{l}\text { (Ferguson \& } \\
\text { Reio, 2010) }\end{array}$ & $\begin{array}{l}\text { The findings of the study indicated that human } \\
\text { resource inputs are not in a relationship with overall } \\
\text { business performance. }\end{array}$ & $\begin{array}{l}\text { The study included 350 business } \\
\text { professionals from US } \\
\text { professional organizations. }\end{array}$ \\
\hline
\end{tabular}

Source: Developed for this research

Finally, the individual results from articles tion about the authors, the findings, and additional published between 2012 and 2018 are presented in research details are provided.

Table 5. Similarly to the previous tables, informa-

Table 5: Results of individual studies published between 2012 and 2018.

\begin{tabular}{|c|l|l|l|}
\hline ID & \multicolumn{1}{|c|}{ Authors } & \multicolumn{1}{|c|}{ Findings } \\
\hline A20 & $\begin{array}{l}\text { (Bučiūniene } \\
\text { Kazlauskaite, } \\
2012)\end{array}$ & $\begin{array}{l}\text { The study suggests that there is a link between HRM, } \\
\text { corporate social responsibility and organizational } \\
\text { performance. Additionally, it was found that the } \\
\text { strategic role of HRM has a positive impact on } \\
\text { organizational performance, and financial } \\
\text { performance. }\end{array}$ & $\begin{array}{l}\text { Data was collected from 119 } \\
\text { medium and large companies } \\
\text { that employ over 100 workers. }\end{array}$ \\
\hline A21 & $\begin{array}{l}\text { (Corral de } \\
\text { Zubielqui et } \\
\text { al., 2017) }\end{array}$ & $\begin{array}{l}\text { It was found that modern HRM practices have a } \\
\text { moderate importance when it comes to } \\
\text { innovativeness and company performance. }\end{array}$ & $\begin{array}{l}\text { 1204 companies from the } \\
\text { Australian Business register } \\
\text { were surveyed. The obtained } \\
\text { data included three financial } \\
\text { years starting from June 2010 } \\
\text { up to June 2013. }\end{array}$ \\
\hline A19 & $\begin{array}{l}\text { (Farouk et } \\
\text { al., 2016) }\end{array}$ & $\begin{array}{l}\text { The study concludes that HRM is positively } \\
\text { correlated to organization innovation, enhanced } \\
\text { strategy innovation, and overall organizational } \\
\text { performance. }\end{array}$ & $\begin{array}{l}\text { 165 banks from the United Arab } \\
\text { Emirates participated in the } \\
\text { survey. The survey measured 23 } \\
\text { items regarding human resource } \\
\text { practices. }\end{array}$ \\
\hline A23 & $\begin{array}{l}\text { (Foss et al., } \\
\text { 2015) }\end{array}$ & $\begin{array}{l}\text { This extensive study discussed that employees who } \\
\text { are rewarded for their hard work are more likely to } \\
\text { share knowledge, thus the knowledge-sharing } \\
\text { human-resource management motivates employees, } \\
\text { indirectly enhancing productivity. }\end{array}$ & $\begin{array}{l}\text { Danish car parts } \\
\text { manufacturing companies with } \\
\text { more 18760 than employees } \\
\text { from which 8855 participated in } \\
\text { the research. The data was } \\
\text { obtained via surveys. }\end{array}$ \\
\hline
\end{tabular}


Table 5: Results of individual studies published between 2012 and 2018. (extension)

\begin{tabular}{|l|l|l|l|}
\hline A24 & $\begin{array}{l}\text { (Glaister et } \\
\text { al., 2018) }\end{array}$ & $\begin{array}{l}\text { This research examined the relationship between } \\
\text { HRM practices, employee performance, training and } \\
\text { developing skills, recruitment process, and overall } \\
\text { business performance. Based on the results, it was } \\
\text { concluded that effective HRM strategies have a } \\
\text { positive relationship with overall employee } \\
\text { satisfaction, and business performance. }\end{array}$ & $\begin{array}{l}\text { The survey was sent to 800 } \\
\text { Turkish companies with no less } \\
\text { than 50 employees. 198 } \\
\text { companies responded with } \\
\text { eligible surveys. }\end{array}$ \\
\hline A22 & $\begin{array}{l}\text { (Mallén et } \\
\text { al., 2015) }\end{array}$ & $\begin{array}{l}\text { In this research it was pointed out that excellent } \\
\text { HRM organizations positively influences the } \\
\text { organization's capability to learn and improve } \\
\text { business strategy outcomes. }\end{array}$ & $\begin{array}{l}\text { 251 companies who } \\
\text { demonstrated superior HRM } \\
\text { performance participated in the } \\
\text { survey. }\end{array}$ \\
\hline
\end{tabular}

Source: Developed for this research

\section{Synthesis of results}

For this systematic review, 25 articles in the domain of HRM and business performance were analysed. In the previous section the results of individual articles were presented. Next, the synthesis of the results is conducted. In Table 6, the sum of sample sizes is presented per article. Further, the articles are grouped by the influence of HRM on business performance and other business metrics, and employee metrics.

Table 6: Sum of samples of reviewed articles

\begin{tabular}{|c|c|c|c|}
\hline \multicolumn{2}{|c|}{ Positive impact of HRM on business performance } & \multicolumn{2}{|c|}{$\begin{array}{l}\text { Negative impact, or non-existing impact of HRM } \\
\text { on business performance }\end{array}$} \\
\hline Article & Sample size & Article & Sample size \\
\hline A3 & 760 companies & A10 & no data \\
\hline A15 & 1 company & A12 & 10 companies \\
\hline A11 & 3702 companies & A14 & 326 companies \\
\hline A6 & 107 companies & A13 & no data \\
\hline A16 & no data & A7 & 137 companies \\
\hline A4 & no data & A5 & 366 companies \\
\hline A17 & 132 companies & $\mathrm{A} 2$ & 727 companies \\
\hline A20 & 119 companies & A19 & 350 companies \\
\hline A18 & 439 hotels & & \\
\hline A9 & 132 companies & & \\
\hline A25 & 251 companies & & \\
\hline A24 & 198 companies & & \\
\hline A8 & 73 companies & & \\
\hline A1 & 1050 companies & & \\
\hline A21 & 1204 companies & & \\
\hline $\mathrm{A} 22$ & 165 companies & & \\
\hline A23 & 6 companies & & \\
\hline $\begin{array}{l}\text { Sum of articles with } \\
\text { positive impact: } 17\end{array}$ & $\begin{array}{l}\text { Sum of sample sizes: } \\
8339\end{array}$ & $\begin{array}{l}\text { Sum of articles with } \\
\text { negative or non-existent } \\
\text { impact: } 8\end{array}$ & $\begin{array}{l}\text { Sum of sample sizes: } \\
1916\end{array}$ \\
\hline
\end{tabular}

Source: Developed for this research

Table 3 presents the number of articles that reported positive relationship between HRM on business performance, and the number of articles that reported negative or no impact on business performance. In addition, the sum of samples of the articles is presented. However, it is important to note, that the sum of samples doesn't mean causality nor has major significance. The results presented in Table 6 are visually depicted in Figure 2. 


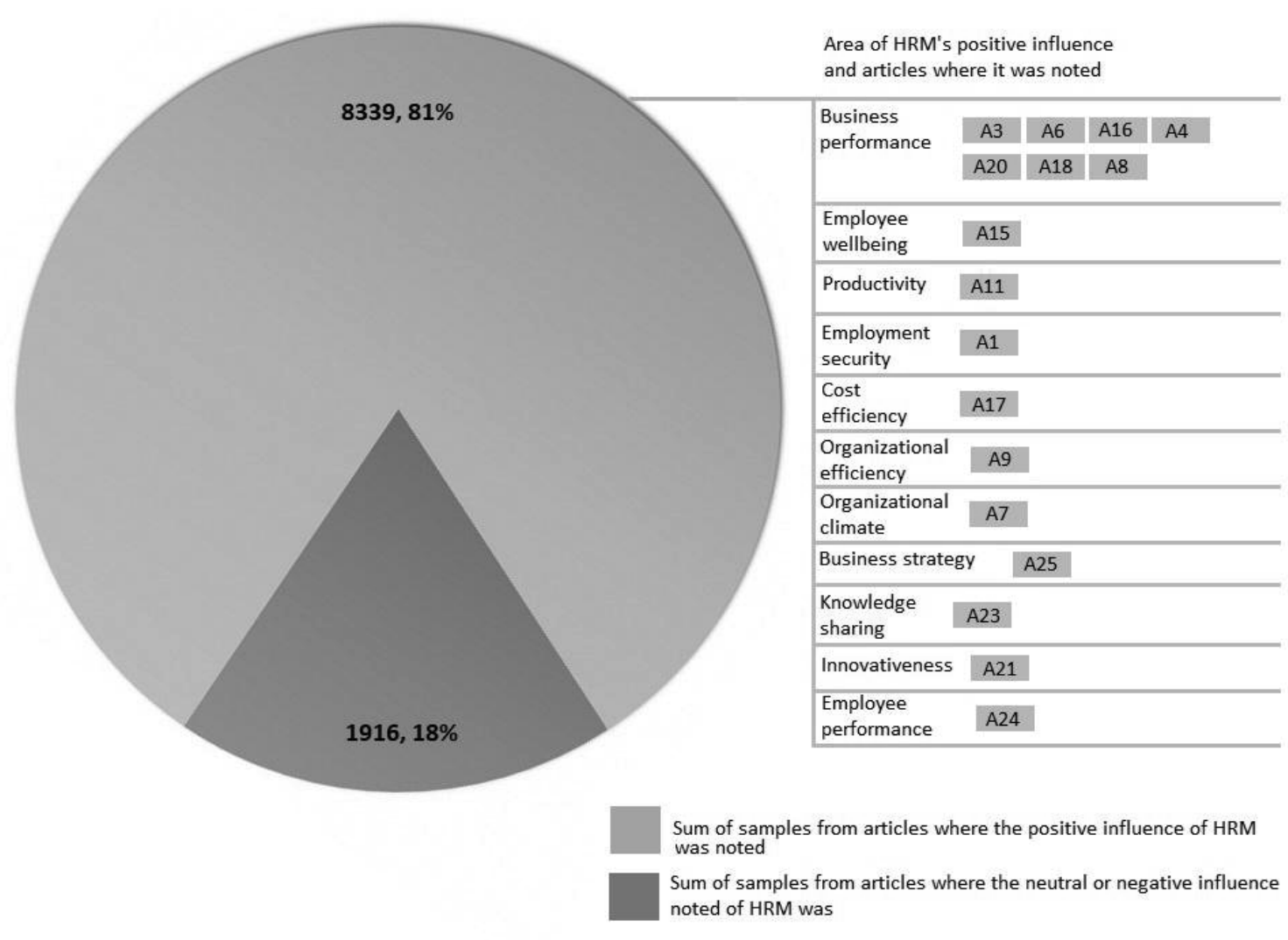

Figure 2: Sum of samples and area of positive HRM influence

As mentioned before, Figure 2 depicts sum of samples, and more importantly, the areas where HRM has a positive impact. In the next section the results are discussed.

\section{DISCUSSION}

Based on the individual review of the results it is evident that HRM has a certain influence on business performance. Similarly to the results of a quantitative review conducted by (Van De Voorde et al., 2012), this present review argues that HRM systems are effective for increasing employee productivity. However, (Van De Voorde et al., 2012) also noted that employee health, and wellbeing is not strongly correlated to HRM practices. Furthermore, an extensive meta-analysis of HRM practices and firm performance, conducted by (Saridakis et al., 2017), reported a correlation value of 0.287 . Even more interesting is that the findings of (Katou \& Budhwar, 2010) suggest that there is possibility of reverse causation. More precisely, high organizational performance may improve HRM practices. This is rather important for future research. It can be assumed that HRM practices shouldn't be the main goal of SMEs but rather achieving high business performance and the good HRM practices will follow. If managers are focusing heavily on HRM there is a chance that the other side of business activities will have lower performance. Certainly, there are SMEs where the employees are satisfied with their workplace but productivity and quality are low. Assuming that good HRM practices are the result of good business performance the question arises that: Is HRM practice development a necessary aspect of business or can it be applied in other forms (ex. managers, or in worst-case scenarios legal representation of conflicted employees)? In order to address this issue in-depth it is necessary to conduct a structured research involving SMEs but large corporations as well.

In this present review paper, the approach was different than to the fore-mentioned findings. Through non-biased article analysis, the goal was to extract as much useful information as possible, but at the same time to provide a concise review of the observed subject. After the conducted review process, the research questions proposed in the "Introduction" section are now addressed:

\section{How does HRM affect overall business performance?}


Based on the collected data from various credible articles, this paper suggests that there might be a positive influence of HRM practices on overall business performance. In addition, there are other metrics that may be influenced, even more so than business performance. These metrics are employee security, employee wellbeing, and organizational climate. These assumptions may not be totally in-sync with the obtained results. Namely, the majority of articles reported improvement in overall business performance. However, if the negative or neutral aspects of HRM are also taken into consideration, then the business performance and HRM link is arguable.

2. Are HRM systems an imperative for high performance in companies?

The extensive analysis of literature in the domain of HRM allows to assume with certain confidence that HRM systems, and practices are not necessary for high business performance in a company. However, HRM can lead to positive results when it comes to employee's position (job security, job satisfaction, initiative, and wellbeing).

\section{Is HRM a necessity for good relationships} between employees?

This present review, and the results from other studies (Alfes et al., 2012; Den Hartog et al, 2012) suggest that efficient HRM practices are indeed important for good relationships between employees, including managers and their subordinates. However, if the organizational culture, and climate nurtures productivity, and positive attitude of employees, while not utilizing any formal HRM practices, then the necessity of the same is questionable. Thus, the internal and external working environment may have a larger role in the HRM-employee relationship construct.

\section{CONCLUSION}

In this paper, the influence of HRM practices and systems on business performance were investigated. In addition, the overall positive aspects of HRM were analysed. Now, the results in this present systematic review tend towards the conclusion that HRM has, indeed, a positive correlation with business performance. The majority of the obtained articles suggested that, undoubtedly, there is a link between good HRM practices and other business performance metrics.
In contrast, there are studies that have argued the neutral or even negative impact of HRM on overall performance of companies. Namely, there is a possibility that overly formal approach to employee relationships may annul the potential positive aspects of HRM systems. The main limitation of this research is the lack of categorizing articles by time periods and research samples. This would've shown how larger and smaller organizations are affected by HRM. However, the mentioned limitation is not severe and doesn't affect the main goal of this present paper.

This study moderately contributes to the existing body of literature. It gives a concise view on HRM influence on business performance. In addition, a large set of other business metrics is also investigated such as employee wellbeing, employee productivity, and organizational climate. Certainly, there is room for further research. It is recommended to address additional sources regarding HRM practices and to add even more business metrics to create a larger "picture" of the HRM-business performance relationship.

\section{REFERENCES}

Ahmad, S., \& Schroeder, R. G. (2003). The impact of human resource management practices on operational performance: recognizing country and industry differences. Journal of Operations Management, 21(1), 19-43.

Akhtar, S., Ding, D. Z., \& Ge, G. L. (2008). Strategic HRM practices and their impact on company performance in Chinese enterprises. Human Resource Management, 47(1), 15-32. doi: 10.1002/hrm.20195

Alfes, K., Shantz, A., \& Truss, C. (2012). The link between perceived HRM practices, performance and well-being: the moderating effect of trust in the employer. Human Resource Management Journal, 22(4), 409-427. doi: 10.1111/1748-8583.12005

Apospori, E., Nikandrou, I., Brewster, C., \& Papalexandris, N. (2008). HRM and organizational performance in northern and southern Europe. The International Journal of Human Resource Management, 19(7), 1187-1207. doi: $10.1080 / 09585190802109788$

Bae, J., \& Lawler, J. J. (2000). Organizational and HRM strategies in Korea: Impact on firm performance in an emerging economy. Academy of Management Journal, 43(3), 502-517.

Bartram, T., Stanton, P., Leggat, S., Casimir, G., \& Fraser, B. (2007). Lost in translation: exploring the link between HRM and performance in healthcare. 
Human Resource Management Journal, 17(1), 2141.

Björkman, I., \& Xiucheng, F. (2002). Human resource management and the performance of Western firms in China. The International Journal of Human Resource Management, 13(6), 853-864. doi: $10.1080 / 09585190210134246$

Boselie, P., Dietz, G., \& Boon, C. (2005). Commonalities and contradictions in HRM and performance research. Human Resource Management Journal, 15(3), 67-94.

Bučiūnienè, I., \& Kazlauskaite, R. (2012). The linkage between HRM, CSR and performance outcomes. Baltic Journal of Management, 7(1), 5-24. doi: $10.1108 / 17465261211195856$

Chand, M., \& Katou, A. A. (2007). The impact of HRM practices on organisational performance in the Indian hotel industry. Employee Relations, 29(6), 576-594. doi: 10.1108/01425450710826096

Collins, C. J., \& Clark, K. D. (2003). Strategic human resource practices, top management team social networks, and firm performance: The role of human resource practices in creating organizational competitive advantage. Academy of Management Journal, 46(6), 740-751.

Corral de Zubielqui, G., Fryges, H., \& Jones, J. (2017). Social media, open innovation \& HRM: Implications for performance. Technological Forecasting and Social Change. doi: 10.1016/j.techfore.2017.07.014

Datta, D. K., Guthrie, J. P., \& Wright, P. M. (2005). Human resource management and labor productivity: does industry matter? Academy of Management Journal, 48(1), 135-145.

Delaney, J. T., \& Huselid, M. A. (1996). The impact of human resource management practices on perceptions of organizational performance. Academy of Management Journal, 39(4), 949-969.

Delery, J. E., \& Doty, D. H. (1996). Modes of theorizing in strategic human resource management: Tests of universalistic, contingency, and configurational performance predictions. Academy of Management Journal, 39(4), 802-835.

Den Hartog, D. N., Boon, C., Verburg, R. M., \& Croon, M. A. (2012). HRM, Communication, Satisfaction, and Perceived Performance. Journal of Management, 39(6), 1637-1665. doi: $10.1177 / 0149206312440118$

Đorđević, D., Ćoćkalo, D., \& Bogetić, S. (2016). The Analysis of Marketing Concept Implementation in Domestic Enterprises. Journal of Engineering Management of Competitiveness, 6(2), 120-128.

Farouk, S., Kumar Singh, T. F. B. a. S., Abu Elanain, H. M., Obeidat, S. M., \& Al-Nahyan, M. (2016). HRM practices and organizational performance in the UAE banking sector. International Journal of Productivity and Performance Management, 65(6), 773-791. doi: 10.1108/ijppm-01-2016-0010

Ferguson, K. L., \& Reio, T. G. (2010). Human resource management systems and firm performance. Journal of Management Development, 29(5), 471-494. doi: 10.1108/02621711011039231

Foss, N. J., Pedersen, T., Reinholt Fosgaard, M., \& Stea, D. (2015). Why Complementary HRM Practices Impact Performance: The Case of Rewards, Job Design, and Work Climate in a Knowledge-Sharing Context. Human Resource Management, 54(6), 955-976. doi: 10.1002/hrm.21649

Gelade, G. A., \& Ivery, M. (2003). The impact of human resource management and work climate on organizational performance. Personnel Psychology, 56(2), 383-404.

Gerhart, B. (2005). Human resources and business performance: Findings, unanswered questions, and an alternative approach. Management Revue, 16(2), 174-185.

Glaister, A. J., Karacay, G., Demirbag, M., \& Tatoglu, E. (2018). HRM and performance-The role of talent management as a transmission mechanism in an emerging market context. Human Resource Management Journal, 28(1), 148-166. doi: 10.1111/1748-8583.12170

Guest, D. E., Michie, J., Conway, N., \& Sheehan, M. (2003). Human resource management and corporate performance in the UK. British Journal of Industrial Relations, 41(2), 291-314.

Harel, G. H., \& Tzafrir, S. S. (1999). The effect of human resource management practices on the perceptions of organizational and market performance of the firm. Human Resource Management, 38(3), 185-199.

Katou, A. A., \& Budhwar, P. S. (2010). Causal relationship between HRM policies and organisational performance: Evidence from the Greek manufacturing sector. European Management Journal, 28(1), 25-39. doi: 10.1016/j.emj.2009.06.001

Lambooij, M., Sanders, K., Ferry, K., \& Zwiers, M. (2006). Human Resource Practices and Organisational Performance: Can the HRMperformance linkage be explained by the cooperative behaviours of employees? Management Revue, 17(3), 223-240.

Lee, F.-H., Lee, T.-Z., \& Wu, W.-Y. (2010). The relationship between human resource management practices, business strategy and firm performance: evidence from steel industry in Taiwan. The International Journal of Human Resource Management, 21(9), 1351-1372. doi: 10.1080/09585192.2010.488428

Mallén, F., Chiva, R., Alegre, J., \& Guinot, J. (2015). Organicity and performance in excellent HRM organizations: the importance of organizational learning capability. Review of Managerial Science, 10(3), 463-485. doi: 10.1007/s1 1846-014-0164-2

Moher, D., Liberati, A., Tetzlaff, J., Altman, D. G., \& Group, P. (2010). Preferred reporting items for systematic reviews and meta-analyses: the PRISMA 
M. Bakator Impact of human resource management on business performance:

et al. A review of literature

statement. International Journal of Surgery, 8(5), 336-341.

Pološki Vokić, N., \& Vidović, M. (2008). HRM as a Significant Factor for Achieving Competitiveness through People: The Croatian Case. International Advances in Economic Research, 14(3), 303-315. doi: 10.1007/s11294-008-9156-9

Renee Baptiste, N. (2008). Tightening the link between employee wellbeing at work and performance: A new dimension for HRM. Management Decision, 46(2), 284-309. doi: 10.1108/00251740810854168

Saha, N., Gregar, A., \& Sáha, P. (2017). Organizational agility and HRM strategy: Do they really enhance firms' competitiveness? International Journal of Organizational Leadership, 6(3), 323.

Saridakis, G., Lai, Y., \& Cooper, C. L. (2017). Exploring the relationship between HRM and firm performance: A meta-analysis of longitudinal studies. Human Resource Management Review, 27(1), 87-96. doi: 10.1016/j.hrmr.2016.09.005

Stavrou, E. T., \& Brewster, C. (2005). The configurational approach to linking strategic human resource management bundles with business performance: myth or reality? Management Revue, 16(2), 186-201.

Stavrou, E. T., Brewster, C., \& Charalambous, C. (2010). Human resource management and firm performance in Europe through the lens of business systems: best fit, best practice or both? The International Journal of Human Resource Management, 21(7), 933-962. doi: $10.1080 / 09585191003783371$

Subramony, M. (2009). A meta-analytic investigation of the relationship between HRM bundles and firm performance. Human Resource Management, 48(5), 745-768. doi: 10.1002/hrm.20315

Sun, L.-Y., Aryee, S., \& Law, K. S. (2007). Highperformance human resource practices, citizenship behavior, and organizational performance: A relational perspective. Academy of Management Journal, 50(3), 558-577.

Van De Voorde, K., Paauwe, J., \& Van Veldhoven, M. (2012). Employee Well-being and the HRMOrganizational Performance Relationship: A Review of Quantitative Studies. International Journal of Management Reviews, 14(4), 391-407. doi: 10.1111/j.1468-2370.2011.00322.x

Vanhala, S., \& Tuomi, K. (2006). HRM, company performance and employee well-being. Management Revue, 3(17), 241-255.

Wall, T. D., \& Wood, S. J. (2016). The romance of human resource management and business performance, and the case for big science. Human Relations, 58(4), 429-462. doi: $10.1177 / 0018726705055032$

\title{
UTICAJ UPRAVLJANJA LJUDSKIM RESURSIMA NA POSLOVNE PERFORMANSE: SISTEMATSKI PREGLED LITERATURE
}

\begin{abstract}
U ovom radu analizira se uticaj upravljanja ljudskim resursima (ULJR) na poslovne performanse kompanija. Glavni cilj je bio temeljna i sistematska analiza literature u domenu upravljanja ljudskim resursima i poslovnih performansi. Veliki broj literaturnih izvora se bavi odnosom između ULJR i poslovnih performansi. Ukupno 212 naučnih radova je analizirano i od toga je uklonjeno 187 u istraživačko-preglednom procesu. Rezultati ovog preglednog rada ukazuju na to da postoji pozitivan odnos između ULJR i poslovnih performansi kompanija. Dodatno, ULJR pozitivno utiče na blagostanje zaposlenih, produktivnost i organizacionu klimu. Međutim, postoji mogućnost da ULJR nije uzrok dobrih poslovnih performansi, već rezultat istih. Ova mogućnost se dalje diskutuje u samom radu. Na osnovu prikupljenih podataka, i dobijenih rezultata, može se tvrditi da ovaj rad ima značajan doprinos literaturi u ovom domenu. Dalje, ovaj rad se može koristiti kao početna tačka za dalja istraživanja i analize ULJR.
\end{abstract}

Ključne reči: Upravljanje ljudskim resursima, Poslovne performanse, Produktivnost zaposlenih, Poslovna strategija. 